Original Research Paper

\title{
Pengembangan Ekonomi Kreatif Berbasis Potensi Desa Desa Demi Terwujudnya Agrowisata Desa Saribaye Kecamatan Lingsar
}

\author{
Embun Suryani ${ }^{1}$, Diswandi ${ }^{2}$, L. M. Furkan ${ }^{3}$, Muhammad An Nagib A. Smith ${ }^{4}$, M. Ali ${ }^{5}$ \\ ${ }^{1}$ Fakultas Ekonomi dan Bisnis, Universitas Mataram, Mataram,Indonesia; \\ ${ }^{2}$ Fakultas Ekonomi dan Bisnis, Universitas Mataram, Mataram,Indonesia \\ ${ }^{3}$ Fakultas Ekonomi dan Bisnis, Universitas Mataram, Mataram,Indonesia; \\ ${ }^{4}$ Program Studi Hubungan Internasional, Universitas Mataram, Indonesia; \\ ${ }^{5}$ Fakultas Peternakan, Universitas Mataram, Mataram,Indonesia.;
}

https://doi.org/10.29303/jpmpi.v3i2.977

Sitasi: Suryani, E., Diswandi., Furkan, L. M., Smith, M. A. N. A \& Ali, M. (2021). Pengembangan Ekonomi Kreatif Berbasis Potensi Desa Desa Demi Terwujudnya Agrowisata Desa Saribaye Kecamatan Lingsar . Jurnal Pengabdian Magister Pendidikan IPA, 4(3)

\author{
Article history \\ Received: 31 Agustus 2021 \\ Revised: 20 September 2021 \\ Accepted: 22 September 2021 \\ *Corresponding Author: \\ Embun Suryani, Universitas \\ Mataram, Mataram, Indonesia \\ Email: \\ embunsuryani@unram.ac.id
}

\begin{abstract}
Desa Saribaye merupakan desa yang terletak pada Kecamatan Lingsar, Kabupaten Lombok Barat, yang dimana desa ini memiliki potensi untuk menjadi sebuah desa yang berbasis agroekowisata yang cukup besar terutama wisata yang memanfaatkan alamnya. Upaya-upaya untuk pengembangan potensi agroekowisata ini diperlukan untuk membantu peningkatan kesejahteraan masyarakatnya, salah satunya adalah dengan meningkatkan perekonomian desa dengan mengembangkan atau menciptakan mata pencaharian ekonomi kreatif, yang memanfaatkan potensi-potensi yang ada pada desa tersebut. Kegiatan pengabdian ini bertujuan untuk membantu Desa Saribaye dalam melakukan pengembangan ekonomi kreatif tersebut, mulai dari pencarian potensi, hingga perancangan, pembuatan hingga pemasaran produk yang telah memiliki nilai ekonomis untuk dijual. Hasil dari pelaksanaan kegiatan ini ditunjukkan dengan terbentuknya berbagai produk yang bernilai ekonomis, yaitu keripik pisang, lilin aromaterapi, abon ikan nila, serta jamur krispi. Pada kegiatan ini, kelompok sasaran didampingi juga untuk melakukan pemasaran terhadap produk-produk yang telah dihasilkan tersebut melalui platform media sosial, seperti facebook market place dan Instagram.
\end{abstract}

Keywords: Agrowisata, Desa Saribaye, Produk Olahan, Pendapatan Masyarakat Desa

\section{Pendahuluan}

Undang - Undang Negara Republik Indonesia Nomor 6 tahun 2014 Tentang Desa, menjelaskan bahwa desa merupakan organisasi pemerintahan terkecil, terbawah, terdepan dan terdekat dengan masyarakat. Desa merupakan titik fokus pemerintah untuk meningkatkan kesejahteraan. Dapat dikatakan bahwa kemajuan sebuah negara sangat tidak terlepas dari perkembangan oleh desa tersebut, dikarenakan sebuah negara tidak bisa maju apabila provinsinya tidak maju, begitu pula tidak ada provinsi yang maju tanpa kabupaten/kota yang maju, dan tidak pula maju sebuah kabupaten/kota yang maju mustahil tanpa adanya desa/kelurahan yang maju pula. Ini berarti bahwa basis kemajuan sebuah negara ditentukan oleh kemajuan desa. (Agunggunanto, 2016). 
Desa Saribaye merupakan salah satu desa yang memiliki sumber daya alam yang sangat beragam, khususnya pada sektor agrikultural dan perikanan. Selain itu, Desa Saribaye juga memiliki berbagai macam jenis usaha mikro kecil dan menengah (UMKM) yang bertujuan untuk menunjang perekonomian desa. Salah satu dari UMKM Desa Saribayea dalah usaha hasil kerajinan tangan, yaitu anyaman ketak. Desa Saribaye sendiri merupakan sebuah desa yang terletak di Kecamatan Lingsar, Kabupaten Lombok Barat, Provinsi Nusa Tenggara Barat. Desa Saribaye terdiri dari lima dusun di dalamnya, dengan total jumlah penduduk sebanyak dua ribu empat ratus dua puluh enam jiwa. Sekitar empat puluh persen dari penduduk Desa Saribaye memiliki mata pencaharian sebagai buruh tani, buruh bangunan dan pedagang keliling. Desa Saribaye merupakan desa yang memiliki potensi alam, lingkungan dan budaya yang sangat penting untuk mendukung dikembangkannya Sentra Agroekowisata. Preferensi wisatawan berkembang secara dinamis, dimana kecenderungan pemenuhan kebutuhan dalam bentuk menikmati obyek-obyek spesifik seperti udara segar, pemandangan yang indah dan hijau, pengolahan produk secara tradisional, maupun produk- produk pertanian modern dan spesifik menunjukkan peningkatan yang pesat. (Pamulardi, 2006).

Disamping itu sentra agroekowisata merupakan tujuan wisata alternatif yang menyajikan berbagai pengalaman unik, menarik dan dengan harga yang relatif lebih murah dibanding tujuan wisata lainnya. Selain potensi alamnya yang sangat indah, wilayah di Kecamatan Lingsar termasuk Desa Saribaye juga dikenal sebagai penghasil buah-buahan terbesar di NTB, misalnya manggis, rambutan, durian, papaya, jambu dan mangga. Potensi ini mendukung pengembangan budidaya madu trigona yang sudah mulai dipelihara oleh beberapa masyarakat dapat dijadikan salah satu produk unggulan di Desa Saribaye. Budidaya madu trigona di Desa Saribaye berpotensi untuk dikembangkan menjadi atraksi agroekowisata dijadikan produk oleh-oleh (Suryani, 2021).

Namun, Desa Saribaye sendiri merupakan desa yang tergolong dengan tingkat pendapatan daerah yang masih rendah. Hal ini dapat dilihat dari rata-rata tingkat pendapatan masyarakat desa yang kebanyakan berprofesi sebagai buruh dan pedagang keliling. Selain itu juga, hal ini dapat terlihat dari tingkat pendidikan penduduk desa yang melanjutkan ke jenjang perguruan tinggi hanya sekitar dua persen dari total populasi penduduk desa. Masyarakat dari Desa Saribaye dapat terbilang menjalani kehidupan yang sederhana dan tradisional. Perekonomian masyarakat Desa Saribaye ini sangat terdampak dengan adanya Pandemi COVID-19. Keterbatasan akan melakukan kegiatan perniagaan membuat berkurangnya intensitas dari pendapatan desa, sehingga menyusahkan masyarakat, khususnya dalam sektor perekonomian. Hal ini membuat resesi atau penurunan dari tingkat perekonomian Desa Saribaye, sehingga sebuah inovasi akan peningkatan kegiatan perekonomian diperlukan.

Dalam dinamikanya, pengembangan dan pemajuan desa tidak hanya terstruktur dilaksanakan oleh pemerintah atau hanya beberapa lembaga yang ada di tingkat desa itu sendiri, melainkan juga peran-peran eksternal yang terlibat (Zulkarnaen, 2016). Salah satu bentuk keterlibatan pihak eksternal yang menjadi focus tulisan ini ialah peranan dari perguruan tinggi (universitas) dalam memberikan bantuan pengembangan dan peningkatan kesejahteraan bagi desa melalui program pengabdian masyarakat. Melalui kegiatan ini diperkenalkan tata cara pengolahan beberapa produk yang memiliki nilai ekonomis, yang dimana hal ini diharapkan dapat menjadi sebuah sektor ekonomi kreatif yang dapat menjadi salah satu sumber pendapatan oleh masyarakat desa. Adapun pengolahan produk yang akan diperkenalkan pada kelompok masyarakat mitra adalah Lilin Aroma Terapi, Keripik Pisang, Abon Ikan Nila, dan Jamur Krispi.

\section{Metode}

Kegiatan pengabdian ini merupakan salah satu bentuk pengabdian masyarakat kemitraan ini dimulai dengan identifikasi permasalahan, proyeksi output, pelaksanaan kegiatan, dan peninjauan kembali hasil kegiatan. Berdasarkan solusi atas permasalahan prioritas desa dan untuk mewujudkan ekonomi kreatif melalui pengembangan usaha pengolahan berbagai produk yang bernilai ekonomis berbasis potensi Desa Saribaye, maka kegiatan ini akan dilakukan melalui pendekatan Participatory Rural Appraisal (PRA) Community development. Kedua pendekatan ini menekankan keterlibatan masyarakat secara langsung sebagai subyek dan obyek dalam pelaksanaan keseluruhan 
kegiatan mulai dari perencanaan, pelaksanaan dan evaluasi program kegiatan. Sedangkan metode yang digunakan untuk memperkenalkan, melatih, dan mendampingi dalam proses pengolahan produk adalah Kaji Tindak Partisipatif melalui pelatihan, pembelajaran, Demonstration plot (Demplot), dan pendampingan secara berkelanjutan dan berkolaborasi dengan kelompok mitra.

\section{Hasil dan Pembahasan}

Sesuai dengan tujuan penelitian, bagian ini menyajikan hasil dan pembahasan dari kegiatan pengabdian masyarakat mulai dari memberikan pengetahuan dan pemahaman tentang rancangan kegiatan yang bertujuan untuk mengembangkan ekonomi kreatif desa, identifikasi dari potensi desa dan kebutuhan masyarakat, serta perumusan kegiatan-kegiatan usaha yang dilakukan untuk menjalankan pengembangan ekonomi kreatif ini. Kegiatan ini secara garis besar terbagi menjadi tiga inti kegiatan, yakni Kegiatan Koordinasi, Kegiatan Pelatihan, Kegiatan Pemasaran. Ketiga rangkaian kegiatan ini sendiri merupakan implementasi dari metode pelaksanaan kegiatan yang telah disusun dan direncanakan oleh tim. Pembagian terhadap kegiatan-kegiatan ini juga merupakan sebuah tahapan yang pada setiap kegiatan memiliki tujuan dan capaian yang masing-masing diharapkan.

\section{Kegiatan Koordinasi}

Untuk mengetahui bagaimana dan sejauhmana perkembangan serta kebutuhan dalam pengembangan dan peningkatan perekonomian desa melalui pembuatan beberapa produk ekonomi kreatif, maka dilakukan preliminary survey melalui wawancara awal kepada para pemangku kepentingan desa seperti kepala desa dan perangkat desa, Badan Permusyawaratan Desa (BPD), kelompok pemuda (Karang Taruna), kepala dusun/kepala wilayah (Kawil), pengelola BUMDes dan beberapa komunitas-komunitas yang ada pada Desa Saribaye. Wawancara ini mengggali informasi tentang bagaimana potensi serta jenis dan kebutuhan dari kewirausahaan yang ada pada masyarakat desa, serta pihak yang dapat dilibatkan dalam pembuatan produk dari ekonomi kreatif ini. Hasil dari tahapan ini menunjukkan bahwa hampir semua pemangku kepentingan desa dan masyarakat dapat berpartisipasi aktif dalam pembentukan dari ekonomi kreatif ini. Mereka menyatakan bahwa dengan dibentuknya beberapa produk ekonomi kreatif diharapkan bisa memberikan kesejahteraan masyarakat, dengan meningkatkan perputaran ekonomi desa dan meningkatkan pendapatan desa dengan menjadi salah satu mata pencaharian yang baru bagi masyarakat desa. Dengan menyerap aspirasi pimpinan desa dan perwakilan kelompok masyarakat dapat dinyatakan bahwa pembentukan usaha ekonomi kreatif di Desa Saribaye berpeluang untuk dilakukan (Gambar 1).
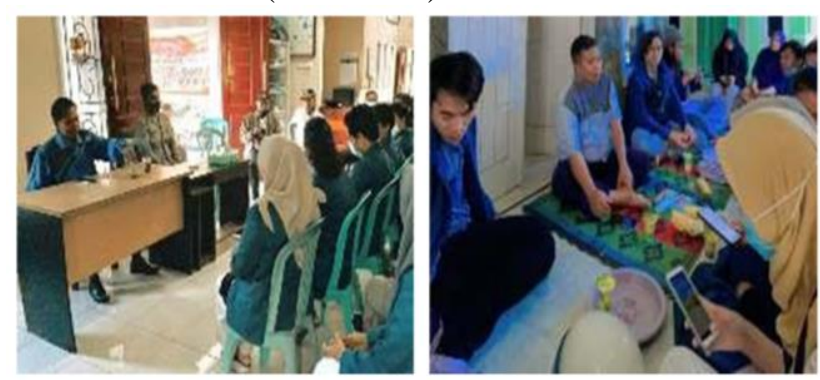

Gambar 1. Koordinasi rancangan kegiatan pengembangan ekonomi kreatif bersama dengan perangkat dan masyarakat desa.

\section{Kegiatan Pelatihan}

Tahap berikutnya yakni pelatihan pembuatan produk ekonomi kreatif. Tim pelaksana pengabdian menyiapkan materi, alat dan bahan pelatihan pembuatan produk berbasis potensi sumber daya alam Desa Saribaye. Untuk pengenalan produkproduk tersebut, kelompok sasaran yang dituju adalah pengolahan jamur krispi bersama dengan KWT An- Nur, pengolahan keripik pisang besama dengan KWT Anugerah Alam Saribaye, pengolahan abon ikan nila bersama dengan Kelompok PKK, serta pengolahan lilin aromaterapi bersama dengan Kelompok Karang Taruna Desa Saribaye.

Untuk pengenalan produk-produk tersebut, kelompok sasaran yang dituju adalah pengolahan jamur krispi bersama dengan KWT An- Nur, pengolahan keripik pisang besama dengan KWT Anugerah Alam Saribaye, pengolahan abon ikan nila bersama dengan Kelompok PKK, serta pengolahan lilin aromaterapi bersama dengan Kelompok Karang Taruna Desa Saribaye.

\subsection{Abon Ikan Nila}

Ikan nila dipilih sebagai bahan baku karena memiliki daging yang tebal, kompak dan mudah dipisahkan dari tulang-tulang dan durinya. Selain itu, ikan nila memiliki kadar lemak $4,1 \%$ dan termasuk ikan berlemak 
sedang, sehingga sesuai digunakan untuk bahan baku abon ikan. Pengolahan abon ikan nila merupakan salah satu upaya diversifikasi pengolahan abon dengan memanfaatkan ketersediaan bahan baku dan karakteristik bahan yang sesuai untuk pengolahan abon. Penggunaan ikan nila pada pengolahan abon ini bertujuan untuk memberi cita rasa dengan sumber bahan alami dan optimalisasi potensi lokal. Sementara itu juga penggunaan ikan nila akan memberikan sumbangan gizi sebesar $17,5 \%$, sedangkan untuk kandungan Karbohidrat 0,32 gram/100 gram daging ikan nila, protein 16,79 gram/ 100 gram, dan lemak 0,18 gram/100 gram.

Penggunaan ikan nila ini tentunya mendukung dalam pemenuhan kebutuhan pangan sehat di pasaran. Produksi abon ikan nila di Desa Saribaye memiliki potensi untuk adanya keberlanjutan hal ini dikarenakan produksi ikan air tawar terutama ikan nila sebagai bahan baku utama abon ikan nila khas Desa Saribaye dirasa cukup tinggi. Dalam kegiatan ini kelompok mitra dilatih dalam proses pembuatan dengan menggunakan perlengkapan yang standar dan higienis serta sebelum pengemasan juga dilakukan sterilisasi terhadap masing-masing kemasan. Gambar 2 berikut ini merupakan abon ikan nila yang dihasilkan oleh Kelompok PKK Desa Saribaye.

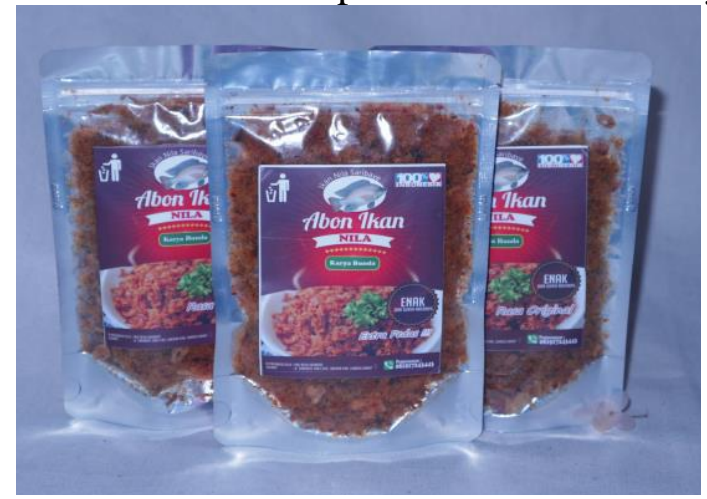

Gambar 1. Abon Ikan Nila Khas Desa Saribaye

\subsection{Kerepik Pisang}

Pisang merupakan salah satu komoditas unggulan yang bisa ditemui di wilayah Desa Saribaye . Dari segi produksinya, pisang mampu memberikan kontribusi antara 40-45\% terhadap produksi buah nasional maupun keragaman penggunaan, seperti buah konsumsi segar, olahan, bahan baku industri, dan pakan ternak. Perkembangan kebun rakyat dan industri olahan di daerah sentra produksi, dapat memberikan peluang baik secara langsung maupun tidak langsung terhadap perluasan kesempatan berusaha dan kesempatan kerja. Industri rumahan saat ini banyak yang membidik produksi makanan berbahan pisang, salah satunya adalah produksi keripik pisang sebab produk yang satu ini paling laris dijadikan oleh-oleh. Keripik pisang berbahan baku pisang muda yang diiris setipis mungkin agar renyah.

Produksi keripik pisang di Desa Saribaye memiliki potensi untuk adanya keberlanjutan hal ini dikarenakan produksi pisang terutama pisang kapok/ambon sebagai bahan baku utama keripik pisang khas Desa Saribaye dirasa cukup tinggi. Selain itu di dalam proses pembuatan dilakukan dengan menggunakan perlengkapan yang standar dan higienis serta sebelum pengemasan juga dilakukan sterilisasi terhadap masing-masing kemasan. Produk pisang ini berpotensi untuk mendukung pengembangan Desa Agrowisata Saribaye. Gambar 3 berikut merupakan kegiatan pengolahan krepek pisang.

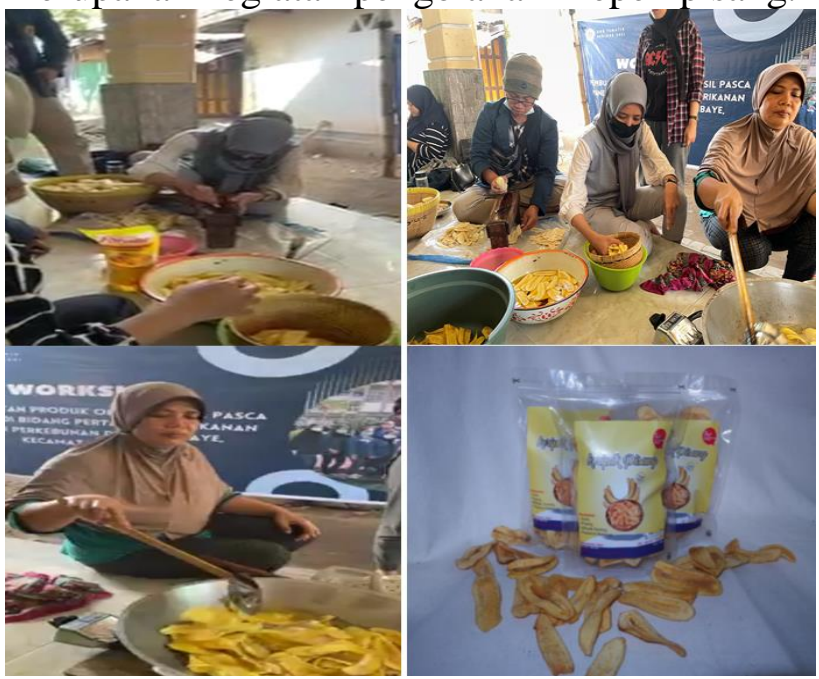

Gambar 3. Kegiatan pengolahan kerepik pisang

\subsection{Jamur Krispi}

Produk pangan olahan berbahan baku lokal dengan citarasa lokal dapat menjadi produk khas 
daerah setempat. Jamur crispy merupakan salah satu produk olahan yang dapat diproduksi oleh Desa Sariabye dan mendukung berkembangnya destinasi agrowisata. Selain dapat sebagai produk oleh-oleh, jamur crispy juga dapat mendukung program diversifikasi pangan lokal di Indonesia dengan percepatan penganekaragaman konsumsi pangan berbasis sumber daya lokal dengan cara memfasilitasi dan mendorong terwujudnya pola konsumsi pangan yang beragam, bergizi seimbang dan aman. Gambar 4 merupakan Jamur crispy yang dihasilkan KWT An-Nur.

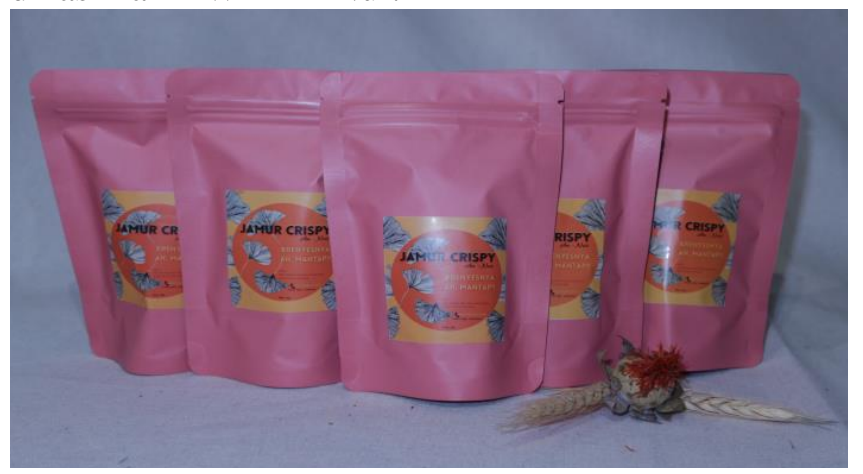

Gambar 4. Jamur Crispy Khas Desa Saribaye

\subsection{Lilin Aromaterapi}

Lilin aromaterapi adalah alternatif aplikasi secara inhalasi (penghirupan), yaitu penghirupan uap aroma yang dihasilkan. Lilin aromaterapi akan menghasilkan aroma yang memberikan efek terapi bila dibakar. Lilin basanya menggunakan bahan paraffin sedangkan lilin yang diolah pada kegiatan ini adalah dengan memanfaatkan limbah pemerasan lebah trigona (beeswax) yang dibudidaya. Sebelumnya, limbah pemerasan ini tidak dimanfaatkan, untuk itu kegiatan ini memberikan solusi pemanfaatan limbah hasil ternak lebah trigona menjadi lilin aromaterapi. Keunggulan bees wax yaitu berasal dari lebah, selain menghasilkan aroma yang manis saat dibakar, lili jenis ini memiliki waktu nyala lebih lama dibandingkan paraffin wax atau paraffin coax. Produksi lilin aromaterapi di Desa Saribaye memiliki potensi untuk adanya keberlanjutan hal ini dikarenakan produksi beeswax sebagai bahan baku utama lilin aromaterapi dirasa cukup tinggi. Gambar 5 berikut kegiatan pengolahan lilin aromateraphy.
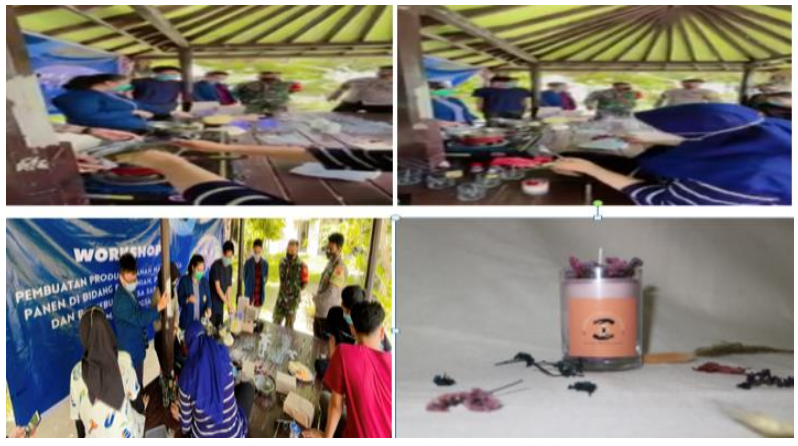

Gambar 5. Kegiatan pengolahan lilin aromateraphy

\section{Pemasaran}

Tahap terakhir dalam pelaksanaan kegiatan pengembangan ekonomi kreatif Desa Saribaye adalah tahap pemasaran. Dalam tahap pemasaran, tim pengabdian telah melakukan sosialisasi dan musyawarah dengan masyarakat desa, khususnya yang menjadi mitra kerja dari pembuatan produk, tentang bagaimana konsep dari pemasaran yang akan dilakukan kelompok mitra terhadap hasil dari produk olahan yang mereka hasilkan. Produk-produk ini kemudian dipasarkan melalui beberapa platform media sosial online, seperti instagram, facebook dan twitter. Selain itu, produk olahan hasil dari kelompok mitra Desa Saribaye ini dipasarkan melalui platform NTB Mall, yang merupakan laman jual beli online yang berbasis hasil UMKM masyarakat NTB. Penjualan melalui platform sosial media ini merupakan metode pemasaran terhadap produk yang dihasilkan desa dengan basis e-commerce.

\section{Kesimpulan}

1. Kegiatan pengabdian kemitraan ini dilaksanakan dengan melakukan berbagai tahapan. Kegiatan yang bertujuan untuk mengembangkan ekonomi kreatif desa ini, dimulai dengan melakukan identifikasi dari potensi desa dan kebutuhan masyarakat, serta perumusan kegiatan-kegiatan usaha yang dilakukan untuk menjalankan pengembangan ekonomi kreatif ini, yang dimana secara garis besar, program ini terbagi menjadi tiga inti kegiatan, yakni Kegiatan Koordinasi, Kegiatan Pelatihan, Kegiatan Pemasaran. Output yang dihasilkan dari pelaksanaan kegiatan pengabdian ini adalah terbentuknya berbagai produk, yakni Lilin Aroma Terapi, Keripik Pisang, Abon Ikan Nila, 
dan Jamur Krispi, yang dimana produk- produk ini di pasarkan melalui beberapa platform jual beli online. Produk-produk yang merupakan bentuk ekonomi kreatif Desa Saribaye ini diharapkan dapat menjadi salah satu pengembangan mata pencaharian desa, yang bertujuan untuk meningkatkan kesejahteraan dan perekonomian warga Desa Saribaye.

2. Dalam melaksanakan setiap kegiatan kelompok mitra masing-masing memberikan kontribusi yang sangat besar dalam setiap kegiatan. Kontribusi mitra sasaran terhadap pelaksanaan ini adalah berupa peran serta dalam setiap kegiatan yang dilakukan, hal ini terlihat dari antusiasme mitra untuk hadir dan ikut dalam melaksanakan setiap kegiatan. Kontribusi mitra juga terlihat dari kesediaan mereka menerima pelaksana pengabdian dengan memberikan sambutan yang ramah dan kesediaan mereka dalam menyediakan lokasi dan ikut berkontribusi untuk menyiapkan bahan baku yang dibutuhkan dalam setiap pelaksanaan kegiatan.

\section{Saran}

Pengolahan berbagai produk berbasis potensi desa dimaksudkan untuk mendukung Desa Saribaye sebagai Desa Agrowisata. Pengembangan destinasi "Desa Agrowisata Saribaye" perlu dilakukan dengan cara melibatkan dinas-dinas terkait sehingga pengembangan destinasi wisata ini dapat dilakukan secara berkelanjutan dan berkesinambungan. Selanjutnya, keberadaan destinasi wisata ini dapat memberikan kontribusi secara signifikan bagi peningkatan perekonomian masyarakat desa. Selain itu, perlu dilakukan pembentukan Desa Saribaye sebagai Desa Agrowisata dengan membuat SK Desa Agrowisata, sehingga dengan legalitas tersebut, pengembangannya dapat dijadikan salah satu desa binaan pemerintah provinsi. Selain itu pemerintah desa perlu membuat masterplan pengembangan Desa Agrowisata Saribaye.

\section{Ucapan Terima Kasih}

Penulis mengucapkan terima kasih kepada Universitas Mataram yang telah memberikan dana melalui insentif Pengabdian PNBP Unram untuk melaksanakan kegiatan pengabdian ini.

\section{Daftar Pustaka}

Agung gunanto, E.Y., Arianti, F., Kushartono, E.W \& Darwanto. (2016). Pengembangan Desa Mandiri Melalui Pengelolaan Badan Usaha Milik Desa (BUMDES). Jurnal Dinamika Ekonomi dan Bisnis, 13(7) : 67-81.

Pamulardi, B. (2006). Pengembangan Agrowisata Berwawasan Lingkungan (Studi Kasus Desa Wisata Tingkir, Salatiga). Tesis, Program Magister Ilmu Lingkungan Program Pascasarjana, Universitas Diponegoro.

Suryani, E., Wahyulina, S., Diswandi., Furkan, L. M., Serif, S., \& Ali, M. (2021). Pemberdayaan Masyarakat melalui Pengembangan Usaha Budidaya Madu Trigona untuk Membentuk Kampong Madu Desa Saribaye Kecamatan Lingsar. Jurnal Pengabdian Magister Pendidikan IPA, 4(2)

Zulkarnaen, Reza M. (2016). Pengembangan Potensi Ekonomi Desa Melalui Badan Usaha Milik Desa (Bumdes) Pondok Salam Kabupaten Purwakarta. Jurnal Aplikasi Ipteks untukMasyarakat, Vol. 5(1): 1-4. 